IZA DP No. 4574

The Impact of Local Decentralization on Economic Growth: Evidence from U.S. Counties

George W. Hammond

Mehmet S. Tosun

November 2009 


\title{
The Impact of Local Decentralization on Economic Growth: Evidence from U.S. Counties
}

\author{
George W. Hammond \\ West Virginia University \\ Mehmet S. Tosun \\ University of Nevada, Reno \\ and IZA
}

\section{Discussion Paper No. 4574 \\ November 2009}

\author{
IZA \\ P.O. Box 7240 \\ 53072 Bonn \\ Germany \\ Phone: +49-228-3894-0 \\ Fax: +49-228-3894-180 \\ E-mail: iza@iza.org
}

\begin{abstract}
Any opinions expressed here are those of the author(s) and not those of IZA. Research published in this series may include views on policy, but the institute itself takes no institutional policy positions.

The Institute for the Study of Labor (IZA) in Bonn is a local and virtual international research center and a place of communication between science, politics and business. IZA is an independent nonprofit organization supported by Deutsche Post Foundation. The center is associated with the University of Bonn and offers a stimulating research environment through its international network, workshops and conferences, data service, project support, research visits and doctoral program. IZA engages in (i) original and internationally competitive research in all fields of labor economics, (ii) development of policy concepts, and (iii) dissemination of research results and concepts to the interested public.
\end{abstract}

IZA Discussion Papers often represent preliminary work and are circulated to encourage discussion. Citation of such a paper should account for its provisional character. A revised version may be available directly from the author. 
IZA Discussion Paper No. 4574

November 2009

\section{ABSTRACT}

\section{The Impact of Local Decentralization on Economic Growth: Evidence from U.S. Counties}

We analyze the impact of fiscal decentralization on U.S. county population, employment, and real income growth. Our findings suggest that government organization matters for local economic growth, but that the impacts vary by government unit and by economic indicator. We find that single-purpose governments per square mile have a positive impact on metropolitan population and employment growth, but no significant impact on nonmetropolitan counties. In contrast, the fragmentation of general-purpose governments per capita has a negative impact on employment and population growth in nonmetropolitan counties. Our results suggest that local government decentralization matters differently for metropolitan and nonmetropolitan counties.

JEL Classification: E62, H7, R11

Keywords: fiscal decentralization, metropolitan, nonmetropolitan, population, employment, income, spatial econometrics

Corresponding author:

George W. Hammond

Bureau of Business and Economic Research

College of Business and Economics

West Virginia University

Morgantown, WV 26506-6025

USA

E-mail: ghammond@wvu.edu 


\section{INTRODUCTION}

Countries around the world, particularly transition economies, have gone through a significant decentralization of their government structures in recent decades.

Decentralization is generally defined as the transfer of certain administrative and fiscal functions or powers of a central authority to several local authorities. The main advantage of local decentralization is that local governments are more efficient (or at least as efficient) at providing certain public services compared to the higher levels of government (Oates, 1972). On the other hand, the theoretical literature in this area argues that there are limits to decentralization and points to an optimal level of fiscal federalism. Some of the limiting factors are listed as tax-benefit linkages, positive spillovers (externalities) of local public goods to neighboring communities and economies of scale involved with the production of the local public good. For example, there is thought to be a trade-off between better treatment of positive externalities through a centralized decision making and loss of local accountability (Oates, 2008).

Arguments for the benefits of decentralization and certain empirical evidence led to a widespread decentralization trend particularly among transition economies. While the U.S. is generally more decentralized compared to most of the developed countries and the OECD average, there is a distinct trend towards more centralization in the U.S. states since 1970 (NCSL, 1997; Brunori, 2003). ${ }^{1}$ The main culprit for this trend is the diminished reliance on property taxes in local financing. There is also a recent movement towards consolidation of certain types of local governments. A recent example of this is the recent merger between the city of Louisville and Jefferson County in Kentucky which was approved in a referendum in 2000. There are also talks about 
possible mergers or public service consolidations in Pittsburgh-Allegheny County (Pennsylvania), Reno-Sparks (Nevada), Buffalo and other locations in upstate New York. Similar consolidations were proposed in West Virginia after recommendations by the West Virginia Commission on Governing in the $21^{\text {st }}$ Century. These different decentralization trends highlight the importance of examining empirically the links between decentralization and certain economic outcomes, particularly economic growth.

In this paper, we examine the relationship between local decentralization and growth using data from metropolitan and nonmetropolitan counties in the U.S. In contrast to the previous literature that has focused on metropolitan statistical areas, we use counties as our geographic unit of analysis. This is important, since counties (and lower levels of government) are often the governmental units with the power to fragment or centralize, either in terms of the number of government units or in terms of revenue generation. This contrasts with metropolitan statistical areas, which usually do not conform to political jurisdictions. We argue that it is important to include nonmetropolitan counties in the analysis since, as Hammond and Thompson (2008) and Higgins et al. (2006) have shown, metropolitan and nonmetropolitan regions differ significantly in their responses to growth determinants. Thus, including nonmetropolitan counties is important in order to avoid selection bias in the results and policy implications.

We also add to the literature by examining multiple dimensions of county fiscal decentralization, including fragmentation measures for both general-purpose and singlepurpose governments, county revenue structure, as well as a measure of local home rule 
power. We also consider the impact of fiscal decentralization on county employment, in addition to population and real income, which is new in the literature.

Finally, we incorporate important spatial relationships into our empirical analysis. We apply spatial econometric techniques (Anselin, 1988; Cliff and Ord, 1981) and as a result we control for important spillovers from county growth shocks. These spillovers may interfere with hypothesis testing, if not properly handled.

Our results show that government organization matters for local economic growth. In addition, the impacts vary by type of government unit and by economic indicator. For instance, we find that special-purpose governments have a significant impact on population and employment growth, but not on income growth. In contrast, we find that county revenue centralization has a significant impact on income growth, but not on either population or income growth. These conflicting results across performance measures are similar to those encountered by Nelson and Foster (1999) and Foster (1993).

Further, our results also highlight significant differences across metropolitan and nonmetropolitan counties, which is consistent with recent theoretical results in Brueckner (2006) and with the results reported in Lobao and Kraybill (2005). Indeed, we find that single-purpose governments more often impact metropolitan growth than nonmetropolitan growth, while general-purpose governments impact nonmetropolitan growth, in contrast to results for metropolitan counties.

The complexity of these results suggests that policy makers should be wary of claims that any and all forms of fiscal decentralization will enhance growth. Instead, we find that particular dimensions of decentralization matter. In addition, we find that 
decentralization has different impacts across population, employment, and income growth, which implies that policy makers should be careful in the claims they make about the benefits and costs of changes to local government organization.

The paper is structured as follows. The next section provides a review of the relevant literature on decentralization and growth. Section 3 lays out our empirical approach and discusses the data used in our regression analysis. Section 4 presents the regression results. The last section provides our concluding remarks.

\section{PREVIOUS STUDIES}

Decentralization is seen as an important avenue for efficiency gains by enabling a direct link between local provision of services and local tastes (Oates 1972, 1993). It is then expected that decentralization helps promote economic growth. Numerous studies examined empirically the relationship between fiscal decentralization and economic growth using data for countries and states. However, after reviewing a variety of past studies on fiscal decentralization and economic growth, Martinez-Vazquez and McNab (2003) concluded that there is no empirical consensus on this relationship. ${ }^{2}$

The focus on countries (or states within countries) makes sense, in that a state which delegates more power to local governments may grow faster than a state which retains power centrally. However, this does not capture all dimensions of fiscal decentralization, which may also occur at the local level. For instance, Boarnet (1998) and Pinto (2007) note there are likely to be spillover effects from decentralization at the local level, including activities related to public infrastructure investment and crime prevention. They point to the possibility of negative economic impacts from decentralization in the presence of local government expenditure spillovers. 
There have been a number of empirical studies devoted to the impact of local government structure on economic growth. Nelson and Foster (1999) and Foster (1993) use similar measures of government organization to analyze two different indicators of growth (population and income), however, the results for individual indicators tend to be different. ${ }^{3}$ For instance, central-city population share is positive, but not significant in the population regression, but is negative and significant in the income regression. Likewise, their measure of special-district fragmentation generates a negative and significant correlation with income growth, but a positive and insignificant correlation with population growth. Differences across these two measures of economic growth may be related to compensating differentials. For example, locations with more favorable government structure (e.g. decentralized local governments) may attract residents which subsequently drive down wages. ${ }^{4}$

In a more recent study, Stansel (2005) extended the local government empirical literature by examining the link between local decentralization and local economic growth during the 1960-1990 period, using a new dataset of 314 U.S. metropolitan statistical areas. He found a negative and significant relationship between the central city share of metro population and population and real per capita income growth and a positive and significant relationship between the number of county governments per metropolitan area resident and population and real per capita income growth. Hence, his study shows evidence of a strong positive relationship between local decentralization and metropolitan statistical area economic growth.

Overall, the empirical work focused on local government structure within metropolitan areas has highlighted a role for fragmentation measures of decentralization, 
but the results have tended to vary by measure of decentralization and by economic indicator.

More recently, there have been efforts to model decentralization theoretically. Brueckner (1999) showed in an overlapping generations (OLG) model that decentralization through young and old jurisdictions affect saving incentives. Brueckner (2006) extended this model to show in an endogenous-growth OLG framework that changing saving incentives also affect human capital investment and economic growth. In this framework, fiscal federalism provides faster economic growth compared to a unitary system. Davoodi and Zou (1998) used a theoretical model similar to Barro (1990) to derive growth maximizing budget shares for federal, state and local governments. They note that "as long as the actual government budget shares are different from growthmaximizing shares, the growth rate can always be increased without altering the total budget's share in GDP” (Davoodi and Zou, 1998, p. 247). ${ }^{5}$

These theoretical models have important implications when we compare the growth effects of decentralization within different regions. A good example is a comparison between metropolitan and nonmetropolitan regions within countries. Brueckner's sorting assumption requires the existence of distinct young and old populations in each region. While U.S. metropolitan regions have a rich composition of young and old generations, nonmetropolitan regions lack such composition. Hence the positive growth results from Brueckner (2006) may not apply to the case of decentralization within nonmetropolitan regions that have relatively older and homogenous populations (Lobao and Kraybill, 2005). Similarly, growth-maximizing budget shares derived by Davoodi and Zou (1998) could be quite different between 
metropolitan and nonmetropolitan regions. In line with the Davoodi and Zou framework, actual budget shares in those regions could give different growth outcomes. ${ }^{6}$ Finally, according to theoretical models of Panizza (1999) and Arzhagi and Henderson (2005), we would expect greater fiscal centralization in nonmetropolitan regions compared to metropolitan regions. This would mean we could get different growth results from decentralization within these regions as there may be too much or too little decentralization in each of these regions. Lobao and Kraybill (2005) provided a timely review of the differences between metropolitan and nonmetropolitan county governments in the U.S. They reported findings from a national survey of county governments. They found that nonmetropolitan counties reported greater fiscal stress due to revenue requirements of decentralization. This finding is particularly important since counties play an important role in the American federal system in promoting local economic development and growth.

\section{EMPIRICAL METHOD AND DATA}

We focus on the impact of local decentralization on long-run population, employment, and real per capita income growth in both metropolitan and nonmetropolitan counties. We focus on the 30-year period from 1970 to 2000, because a period of this length will likely be long enough to bring long-run issues to the fore. We focus on this particular 30-year period in part because it updates previous results in the literature (which have previously focused on the 1970s, 1980s, and 1990s).

We operationalize fiscal decentralization in a multi-dimensional way which acknowledges the complex nature of the issue. This also allows us to investigate the particular types of decentralization which may matter at the county level. We focus 
exclusively on direct measures of government organization (as opposed to populationbased measures employed by Stansel (2005), Nelson and Foster (1999), and Foster (1993)) and we include multiple measures of local government (general purpose and single purpose), which allows us to investigate the importance of increased institutional decentralization (i.e. more special-purpose governments). We also express our measures of local government fragmentation on a per capita and per square mile basis. ${ }^{7}$ Similar fragmentation measures were used, for example, by Zax (1989) for U.S. counties, Nelson (1992) for Swedish local governments and Stansel (2005) for U.S. metropolitan statistical areas.

In general, we interpret an increase in fragmentation as an increase in fiscal decentralization. Following Zax (1989) we interpret fragmentation per square mile as reflecting the jurisdictional competitiveness across space, with more governments per square mile indicating greater competitiveness. Fragmentation per capita reflects the relative influence of economies of scale and spillovers versus the ability to meet local preferences.

In addition to these measures we also examine the impact of government revenue centralization on growth. We follow Zax (1989) by implementing this measure via the ratio of county revenue to total county and local government revenue. This provides an indicator of the degree to which both own-source revenue and intergovernmental transfers are centralized at the county level and thus provides an indication of centralization of economic power in a county. We interpret a decrease in county revenue centralization as an increase in fiscal decentralization. 
We present results for population, employment, and income because these are considered important outcome variables by policymakers and because results may differ across these indicators. Our results for employment growth are new and add to previous results available in the empirical literature on fiscal decentralization. As Glaeser et al. (1995) and Beeson et al. (2001) note, income is likely to be a better indicator of economic performance for countries than for counties within a nation. This is because residents within a nation are likely to move in response to productivity differences (or differences in government organization), but population and employment change will in turn affect productivity and quality of life. Thus, population and employment may be more straightforward indicators of economic performance than income.

Our approach contributes to the literature, in part, because we are interested in exploring these issues for all counties in the lower 48 U.S. states, not just the more populous metropolitan statistical areas. This is important, since county and lower levels of government are often the governmental units with the power to fragment or centralize, either in terms of government units per capita or in terms of revenue generation, in contrast to metropolitan statistical areas. ${ }^{8}$ This is also important in order to avoid possible selection bias in the results and resulting policy implications. As Hammond and Thompson (2008) and Higgins et al. (2006) have shown, the impact of growth determinants differs significantly across metropolitan and nonmetropolitan regions. Further, nonmetropolitan counties accounted for a significant share of the U.S. population in 2004 (at 16.9\%, or 49.7 million residents, using the 1999 MSA designations from the federal Office of Management and Budget). 
In addition to measures of local decentralization, we control for other influences on long-term growth including local human capital, industry employment mix, labor market performance, natural amenities, spatial relationship, the population size of the metropolitan area (for metropolitan counties), state fixed effects, previous growth, and the initial level of the dependent variable. ${ }^{9,10}$ Our empirical specification is generally similar to Glaeser et.al. (1995) and Stansel (2005) in that we use several of the same control variables and use beginning period values for all right-hand side variables, in order to reduce possible endogeneity between our measures of fiscal decentralization (and control variables) and growth. This is likely to be an important issue when analyzing the impact of government policies on growth, since government action is by definition endogenous and likely to be forward looking. ${ }^{11}$ While we do not attempt to instrument fiscal decentralization, we do include lagged growth rates (for the preceeding decade) for our dependent variables in order to control for the effect of growth on fiscal decentralization. Since lagged growth is likely correlated with omitted county fixed effects, including it helps to reduce this source of omitted variable bias.

These formulations are similar to cross-section growth regressions designed to provide results on convergence. Under this interpretation, the control variables (with the exception of the initial level of the dependent variable) determine the steady state growth rate. The initial level variables provide information on the dynamic adjustment to the steady state.

We will identify the impacts of fiscal decentralization on growth by regressing population, employment, and real income growth on our measures of fiscal decentralization and our control variables. Since we use county-level data, it is important 
to account for spatial spillovers across counties. These spillovers may be caused by commuting connections across counties, which imply that growth shocks to one county may be transmitted to other counties nearby, and will cause the residual variance in an ordinary least squares regression to be nonspherical. To correct for this, we use a model of spatial relationship developed by Anselin (1988): the spatial error model. As Anselin (1988) points out, accounting for spatial relationships using the spatial error model will improve the efficiency of resulting hypothesis tests. This model has been estimated in a variety of contexts, including US state income convergence by Garrett et al. (2007) and Rey and Montouri (1999).

We estimate a spatial error model of the following form, in order to differentiate between metropolitan and nonmetropolitan impacts:

$$
\begin{aligned}
& y=\left[\begin{array}{cccc}
F D_{m} & X_{m} & 0 & 0 \\
0 & 0 & F D_{n m} & X_{n m}
\end{array}\right]\left[\begin{array}{c}
\beta_{m}^{F D} \\
\beta_{m}^{X} \\
\beta_{n m}^{F D} \\
\beta_{n m}^{X}
\end{array}\right]+\mu \\
& \mu=\lambda W \mu+\varepsilon
\end{aligned}
$$

where $\mathrm{y}$ is an Nx1 vector containing the dependent variable, in our case population, employment or real income growth rates for $\mathrm{N}$ counties. The matrix $\mathrm{FD}_{\mathrm{m}}$ contains our measures of fiscal decentralization for metropolitan counties $\left(\mathrm{FD}_{\mathrm{nm}}\right.$ for nonmetropolitan counties). The vector ( $\beta_{m}^{F D}$ ( $\beta_{n m}^{F D}$ for nonmetropolitan) contains the coefficients for metropolitan fiscal decentralization measures. The matrix $\mathrm{X}_{\mathrm{m}}\left(\mathrm{X}_{\mathrm{nm}}\right.$ for nonmetropolitan) contains our control variables for metropolitan counties. The vectors 
$\beta_{m}^{X}$ and $\beta_{n m}^{X}$ contain the coefficients for metropolitan and nonmetropolitan counties, respectively.

The matrix $\mathrm{W}$ is an $\mathrm{NxN}$ row standardized spatial weight matrix (the rows sum to one). We choose to model spatial relationships using first-order contiguity, which identifies contiguous neighbors. The term $\varepsilon$ is an Nx1 vector of errors, and $\lambda$ is a parameter to be estimated that shows the degree of spatial dependence among the error terms.

Use of ordinary least squares on Equations 1 and 2 is not appropriate since the spatial error term is non-spherical. However, if $\varepsilon$ is homoskedastic and jointly normally distributed, the model given by Equations 1 and 2 can be estimated via maximum likelihood estimation (Anselin 1988).

Finally, in order to test the degree of heterogeneity across metropolitan and nonmetropolitan counties, we carry out spatial Chow tests for structural stability. As Anselin $(1988,1990)$ shows, the test statistic takes the form:

$$
\left[e_{R}^{\prime}(I-\lambda W)^{\prime}(I-\lambda W) e_{R}-e_{U}^{\prime}(I-\lambda W)^{\prime}(I-\lambda W) e_{U}\right] / \sigma^{2} \sim \chi^{2}(K)
$$

where I is the identity matrix, $\mathrm{R}$ identifies the restricted regression (all coefficients restricted to be equal), $U$ identifies the unrestricted regression (metropolitan coefficients differ from nonmetropolitan coefficients), and $\sigma^{2}$ is the estimate of the error variance from the unrestricted regression.

Our approach utilizes county data for the lower 48 United States. ${ }^{12}$ We use the 1973 metropolitan statistical area definitions which identify 629 counties as metropolitan. We are left with 2,443 nonmetropolitan counties. Thus, we classify counties as metropolitan and nonmetropolitan at the beginning of the period, in order to further 
reduce issues of selection bias. As Table 1 shows, population and employment growth during the 1970-2000 period was much faster on average for metropolitan counties than for nonmetropolitan counties. We find a similar pattern in real per capita income growth, deflated by the CPI-U, with faster growth in metropolitan counties than in nonmetropolitan counties, although the gap is smaller. ${ }^{13}$

\section{[TABLE 1 ABOUT HERE]}

Our control variables include the beginning period values for the dependent variable, the unemployment rate, educational attainment, employment share (excluding agricultural services), the population size of the MSA (excluding the reference county), county amenities, and distance to the nearest metropolitan statistical area and incremental distances to larger MSAs. As Table 1 shows, the number of residents per county tends to be much smaller for nonmetropolitan counties than for their metropolitan counterparts. In 1969, real income in metropolitan counties was $26.5 \%$ above average income for nonmetropolitan counties.

We account for the local unemployment rate, educational attainment, employment mix, population of the metropolitan area (excluding the reference county), county natural amenities, and the local spatial hierarchy. We include the natural amenities scale developed by McGranahan (1999), where a higher value indicates more desirable natural amenity characteristics (such as varied topography, access to water, sunny days in winter, warm winter temperatures, temperate summers, and low summer humidity). We account for the local spatial hierarchy (along the lines suggested by Partridge et al. (2008)) by measuring the distance from a county to the centroid of the closest metropolitan statistical 
area, as well as incremental distances to larger metropolitan areas. As expected, these distances are much shorter for metropolitan counties than for nonmetropolitan counties.

Our main interest is the impact of fiscal decentralization on growth. Table 1 summarizes the data on local governments in U.S. counties in 1972. As Table 1 shows, in 1972 there were 25.9 local governments per county in the United States. Local governments include county, municipal, township, independent and dependent school districts, and special districts. Metropolitan counties reported a higher number of local governments (at 41.5 per county) than did nonmetropolitan counties (at 22.0 per county). Metropolitan counties also registered a larger number of government per square mile (0.133) than did nonmetropolitan counties (0.084). However, on a per capita basis, nonmetropolitan counties registered 176.5 local governments per 100,000 residents, far higher than the metropolitan average of 43.2. This pattern reflects the fact that nonmetropolitan counties are sparsely populated compared to metropolitan counties. Indeed, in 1972, the number of residents per square mile in nonmetropolitan counties was 77.1, compared to the metropolitan average of 574.5.

We sum county, municipal, and township governments, as well as dependent school systems, to measure general-purpose governments. On average across all U.S. counties, general-purpose governments accounted for $50.1 \%$ of total local governments in 1972, at 13.0 per county. General-purpose governments accounted for a larger share of governments in nonmetropolitan counties in 1972, at 52.4\%, than in metropolitan counties, at $45.5 \%$. Similar to results for all local governments, metropolitan counties registered more general-purpose governments per county and per square mile, but fewer general-purpose governments per capita than nonmetropolitan counties. 
We sum independent school districts and special districts to measure singlepurpose governments. On average across all U.S. counties, these governments accounted for one-half of total local governments in 1972. These governments account for a larger share of local government in metropolitan counties than for nonmetropolitan counties. Again, we find that metropolitan counties have more single-purpose governments per county and per square mile, but fewer per capita, than do nonmetropolitan counties.

Special districts accounted for 60.2\% of all single-purpose governments in 1972. As defined by the Census, special district governments are independent, special-purpose governments that exist as separate entities with substantial administrative and financial independence from general-purpose local governments. These governments may be formed to deliver a variety of goods and services, including infrastructure development, water and waste management, parks and recreation, among many others.

In 1972, the revenue centralism averaged 0.317 across all U.S. counties, which implies that on average county governments accounted for 31.7 percent of total county and local government revenue. The county revenue ratio was higher in nonmetropolitan counties, at 0.321 , than in metropolitan counties (0.305).

\section{EMPIRICAL RESULTS}

Our empirical results for population, employment, and real income growth are summarized in Table 2. Results from the spatial Chow test reject the null hypothesis that all coefficients are the same across metropolitan and nonmetropolitan counties at the $1 \%$ significance level. Thus we report separate results for each.

[TABLE 2 ABOUT HERE]

\section{Population Growth}


We begin by examining results for population growth. First, we note a significant positive correlation for single-purpose governments per square mile in metropolitan counties and a significant negative correlation for single-purpose governments per capita. One way to examine the possible net impact is to consider the growth response to an equal percentage increase in single-purpose governments per capita and per square mile. A $10 \%$ increase in single-purpose governments per capita reduces the long-run growth rate by $0.27 \%$, while a $10 \%$ increase in single-purpose governments per square mile increases long-run growth by $0.17 \%$, which leave the net impact of $-0.1 \%$. This suggests that increases in single-purpose governments are likely to modestly reduce long-run metropolitan growth. In turn, this suggests that spillovers and economies of scale may be an important factor in determining the growth impact of special-purpose governments, versus the ability to more precisely cater to local tastes and preferences. These results are similar to Foster (1993) who found no significant relationship between special district dominance, measured as the ratio of special districts to general-purpose governments in a metropolitan statistical area, and population growth.

The results differ for nonmetropolitan counties, with a significant negative coefficient on general-purpose governments per capita, which indicates that this form of local decentralization is associated with slower nonmetropolitan population growth. The estimated coefficients imply that a 10\% increase in general-purpose governments per capita are associated with a $0.36 \%$ decrease in long-run nonmetropolitan population growth. We find no significant correlation for single-purpose governments per capita (or square mile), in contrast to our results for metropolitan counties. 
Since single-purpose governments include both independent school districts and special districts, we further decompose single-purpose governments and present our regression results in Table 3. We find a significant positive correlation on metropolitan special districts per square mile (significant at the $1 \%$ level). Again, the coefficients special-purpose governments for nonmetropolitan counties are not significantly different from zero, indicating important differences across metropolitan and nonmetropolitan counties.

\section{[TABLE 3 ABOUT HERE]}

Overall, our results for population growth suggest that fiscal decentralization may modestly reduce long-run population growth in both metropolitan and nonmetropolitan counties, but for different reasons. We find that special-purpose governments have a significant impact for metropolitan counties, while general-purpose governments have a significant impact on nonmetropolitan county growth.

\section{Employment Growth}

We find a significant correlation for metropolitan special-purpose governments per square mile (and special districts per square mile), similar to our results for population growth. Our estimates imply that a $10 \%$ increase in special-purpose governments per capita increase long-run metropolitan employment growth by $0.1 \%$. For nonmetropolitan counties, we again find a significant negative correlation for generalpurpose government fragmentation and a significantly positive correlation for singlepurpose governments per capita, with the results driven by school district fragmentation per capita (this variable is significant at the $11 \%$ level). Our elasticity estimates suggest that a $10 \%$ increase in general-purpose governments per capita would decrease 
nonmetropolitan employment growth by $0.23 \%$, while a $10 \%$ increase in single-purpose governments per capita would increase employment growth by $0.15 \%$. Thus, the net impact suggests that fiscal decentralization may have a negative impact on nonmetropolitan employment growth.

Overall, the results show differences across metropolitan and nonmetropolitan counties, with general-purpose government fragmentation negatively correlated with nonmetropolitan growth, while we find no significant correlation with metropolitan growth. Further, single-purpose governments per capita are positively correlated with nonmetropolitan employment growth but single-purpose governments per square mile are positively correlated with metropolitan employment growth.

These results suggest that increasing fragmentation of special-purpose governments can boost employment growth, which may reflect the added institutional decentralization afforded by relying on this type of service delivery. Our results suggest that this type of institutional flexibility matters more for labor market outcomes than for residential choices. Further, the reason that special-purpose governments matter for employment growth likely differ across metropolitan and nonmetropolitan regions. For instance, we find a positive correlation between special-purpose governments per square mile and employment growth in metropolitan counties. This suggests that it may be the competitive pressures of many special-purpose governments (mainly special-districts) within the county that drives government efficiency which ultimately benefits employment growth. For nonmetropolitan counties, we find that it is special-purpose governments (mainly school districts) per capita that is positively correlated with employment growth. This suggests that it is the ability to better reflect local tastes and 
preferences (versus economies of scale and efficiency) that affects local employment growth.

\section{Income Growth}

We find that revenue centralization is positively correlated with long-run income growth in metropolitan counties, but no correlation between any of our measures of decentralization and nonmetropolitan income growth. Our estimates imply that a 10\% increase in revenue centralization in metropolitan counties generates a decline in long-run per capita income growth of $0.28 \%$. This suggests that metropolitan fiscal decentralization, of this form, benefits long-run income growth. It also suggests that generating revenue in a decentralized way makes the county a more attractive location for high income individuals and activities.

\section{Results for Control Variables}

Results for the control variables in metropolitan counties are generally similar to those in Glaeser et.al. (1995) and Stansel (2005) and other results in the literature. We find a negative and significant coefficient on initial population, employment, and income (in their respective regressions), for both metropolitan and nonmetropolitan counties. This suggests that counties with initially high levels in 1970 tended to grow slower than counties with low levels in $1970 .^{14}$

We find a positive and significant correlation between initial educational attainment and income growth for both metropolitan and nonmetropolitan counties, similar to Hammond and Thompson (2008) and Higgins et al. (2006). For nonmetropolitan counties, we find a positive and significant correlation for the unemployment rate for population and employment growth, which suggests that 
nonmetropolitan counties with greater labor market slack tend to grow faster. Deller, et al. (2001) report a similar result for the impact of the unemployment rate on population growth in nonmetropolitan counties.

We also find that metropolitan counties which are part of more populous metropolitan areas tend to generate faster income growth and that higher levels of natural amenities are associated with faster income growth for both metropolitan and nonmetropolitan counties (and faster population and employment growth for metropolitan counties). We also report results for spatial hierarchy that are similar to Partridge et al. (2008), in that counties that are closer to larger metropolitan areas generally tend to grow faster.

Finally, we find significant positive spillovers of growth shocks ( $\lambda$ positive and significantly different from zero) across counties. This suggests that counties whose neighbors grow faster than expected also tend to grow faster than expected.

We have included state binary variables in our regressions to control for state policies. However, one aspect of state policymaking affects the degree to which local governments are allowed to control their own destiny. The home rule index introduced by Geon and Turnbull (2006) and updated by Salvino (2007) presents a way to control for this aspect of state policy. This measure relies on the detailed political, economic, and legal information summarized in Krane, et al. (2001) on the freedom granted to local governments by the state authority. This is a multi-dimensional concept that considers the degree to which local governments are allowed to raise and spend revenue, as well as independently undertake other government functions. It is important to keep in mind that the state policies might have evolved during the $1970-2000$ period, and so this measure 
might not be ideal. However, it is the best measure we know of at this time. The index is an ordinal measure ranging from 1.0 to 4.0, with a score of 1.0 given to states which allocate to local governments the least decision making power and a score of 4.0 given to state’s which grant the most freedom to local governments. We assign the state score to each county within the state and replace state binary variables with Census division binary variables. All other fiscal decentralization and control variables are the same. Our results suggest that greater home rule powers positively impact population and employment growth for nonmetropolitan counties, but do not have a statistically significant impact on growth in metropolitan counties. ${ }^{15}$

\section{POLICY IMPLICATIONS AND CONCLUSIONS}

In this paper, we find a great deal of heterogeneity in the impact of various forms of fiscal decentralization across metropolitan and nonmetropolitan counties and across measures of local economic performance. In general, our results suggest that policy makers should also take care to think through not only the form of decentralization being considered, but also the metropolitan/nonmetropolitan character of the county and the goals which are meant to be achieved, because there is likely to be significant heterogeneity in the response to any given policy change.

We find that the growth impacts of fiscal decentralization differ across metropolitan and nonmetropolitan counties. Similar to Stansel (2005), we find evidence that decentralization may contribute to metropolitan growth, particularly for employment and income growth (where we find that increased fragmentation of single-purpose governments boosts employment growth, while reduced revenue centralization increases income growth). In contrast, we find that general-purpose government fragmentation is 
negatively associated with population and employment growth in nonmetropolitan counties. These results are consistent with new results in the theoretical literature, which suggest that fiscal decentralization may be of less benefit to the less demographically diverse nonmetropolitan counties. In turn, our results suggest that policy makers should take into account the metropolitan/nonmetropolitan character of their county when considering possible costs/benefits of local fiscal decentralization.

We also find that the particular form of fiscal decentralization has heterogeneous impacts on economic indicators that matter to local policymakers. For instance, we find that special-purpose governments on balance tend to reduce metropolitan population growth, while special-purpose governments per square mile increase employment growth and have no significant impact on real income growth in metropolitan counties. For nonmetropolitan counties, increases in general-purpose governments per capita tends to reduce population and employment growth, but has no significant impact on income growth. These conflicting results between population (and employment) and income growth are similar to those encountered by Nelson and Foster (1999) and Foster (1993) and can arise from compensating wage differentials driven by increased migration into the county in response to government organization.

In addition, we find that fragmentation of special-purpose governments may spur employment growth for both metropolitan and nonmetropolitan counties, which may reflect the added institutional decentralization created by relying on this method of service delivery. Finally, our results highlight the importance of accounting for spatial relationships in the US county data. We find significant spillovers of growth shocks from county neighbors that should be accounted for in studies of local economic growth. 
Among possible future extensions of this research, we note that it may be useful to examine the same relationship by including the time dimension. Hence, a panel data analysis would enable us to examine both the variations in the number of local government units across metropolitan and nonmetropolitan regions and also variation across time in these regions. In addition, an analysis of counties that have engaged in significant fiscal consolidation or decentralization using quasi-experimental techniques would be quite valuable. 


\section{References}

Akai, Nobuo and M. Sakata. 2002. “Fiscal Decentralization Contributed to Economic Growth: Evidence from State-Level Cross-Section Data for the United States,” Journal of Urban Economics, 52, 93-108.

Anselin, Luc. 1988. Spatial Econometrics: Methods and Models. Dordrecht, Kluwer.

Anselin, Luc. 1990. "Spatial Dependence and Spatial Structural Instability in Applied Regression Analysis," Journal of Regional Science, 30, 185-207.

Arzhagi, Mohammad and J. Vernon Henderson. 2005. "Why Countries are Fiscally Decentralizing,” Journal of Public Economics, 89, 1157-1189.

Barro, Robert. 1990. "Government Spending in a Simple Model of Endogenous Growth," Journal of Political Economy, 98, 103-125.

Beeson, Patricia E., David N. Dejong, and Werner Troesken. 2001. "Population Growth In U.S. Counties, 1840-1990," Regional Science and Urban Economics, 31, 669-699.

Boarnet, Marlon G. 1998. "Spillovers and the Locational Effects of Public Infrastructure," Journal of Regional Science, 38, 381-400.

Brueckner, Jan K. 1999. “Fiscal Federalism and Capital Accumulation,” Journal of Public Economic Theory, 1, 205-224.

Brueckner, Jan K. 2006. “Fiscal Federalism and Economic Growth,” Journal of Public Economics, 90, 2107-2120.

Brunori, David. 2003. Local Tax Policy: A Federalist Perspective, Washington, D.C., The Urban Institute Press.

Cliff, A. and Ord, J. 1981. Spatial Processes: Models and Applications. London, Pion.

Davoodi, H. and H. Zou. 1998. "Fiscal Decentralization and Economic Growth: A Cross-Country Study,” Journal of Urban Economics, 43, 224-257.

Deller, Steven C., Tsung-Hsiu Tsai, David W. Marcouiller, and Donald B.K. English. 2001. "The Role of Amenities and Quality of Life in Rural Economic Growth," American Journal of Agricultural Economics, 83, 352-365.

Foster, Kathryn A. 1993. "Exploring the Links Between Political Structure and Metropolitan Growth,” Political Geography, 12, 523-547. 
Garrett, Thomas A, Gary A. Wagner, and David C. Wheelock. 2007. Regional Disparities in the Spatial Correlation of State Income Growth, 1977-2002,” Annals of Regional Science, 41, 601-618.

Geon, Gyusuck and Geoffrey K. Turnbull. 2006. "Local Government Internal Structure, External Constraints and the Median Voter,” Public Choice, 129, 487-506.

Glaeser, Edward, Jose Scheinkman, and Andrei Shleifer. 1995. "Economic Growth in a Cross-Section of Cities,” Journal of Monetary Economics, 36, 117-143.

Hammond, George W. and Eric C. Thompson. 2008. "Determinants of Income Growth in U.S. Metropolitan and Nonmetropolitan Labor Markets,” American Journal of Agricultural Economics, 90,783-793.

Higgins, Matthew J., Daniel Levy, and Andrew T. Young. 2006. "Growth and Convergence Across the United States: Evidence from County-Level Data,” The Review of Economics and Statistics, 88, 671-681.

Krane, D. N. Rigos, and B. Hill Jr. 2001. Home Rule In America: A Fifty-State Handbook. Washington D.C.: CQ Press.

Lin, Justin Yifu and Zhiqiang Liu. 2000. "Fiscal Decentralization and Economic Growth in China,” Economic Development and Cultural Change, 49, 1-21.

Lobao, Linda and David S. Kraybill. 2005. "The Emerging Roles of County Governments in Metropolitan and Nonmetropolitan Areas: Findings from a National Survey,” Economic Development Quarterly, 19, 245-259.

Martinez-Vaquez, Jorge and R.M. McNab. 2003. "Fiscal Decentralization and Economic Growth,” World Development, 31, 1597-1616.

McGranahan, David. 1999. "Natural Amenities Drive Rural Population Change,” Agricultural Economics Report No. 781, Food and Rural Economics Division, Economic Research Service, U.S. Department of Agriculture.

National Conference of State Legislatures. 1997. Critical Issues in State-Local Fiscal Policy, A Guide to Local Option Taxes. Denver: National Conference of State Legislatures.

Nelson, Arthur C. and Kathryn A. Foster. 1999. "Metropolitan Governance Structure and Economic Growth,” Journal of Urban Affairs, 21, 309-324.

Nelson, Michael A. 1992. "Municipal Amalgamation and the Growth of the Local Public Sector in Sweden,” Journal of Regional Science, 32, 39-53.

Oates, Wallace E. 1972. Fiscal Federalism, New York, Harcourt Brace Jovanovic. 
Oates, Wallace E. 1993. "Fiscal Decentralization and Economic Development," National Tax Journal, 46, 237-243.

Oates, Wallace E. 2008. “On the Evolution of Fiscal Federalism: Theory and Institutions,” National Tax Journal, 61, 313-334.

Partridge, Mark D., Dan S. Rickman, Kamar Ali, and M. Rose Olfert. 2008. "Lost in Space: Population Growth in American Hinterlands and Small Cities,” Journal of Economic Geography, 8, 727-757.

Panizza, Ugo. 1999. “On the Determinants of Fiscal Centralization: Theory and Evidence,” Journal of Public Economics, 74, 97-139.

Pinto, Santiago M. 2007. "Tax Competition in the Presence of Interjurisdictional Externalities: The Case of Crime Prevention,” Journal of Regional Science, 47, 897-913.

Quah, D. 1993. “Galton’s Fallacy and Tests of the Convergence Hypothesis.” Scandinavian Journal of Economics, 95, 427-443.

Rey, Sergio J. and Brett D. Montouri. 1999. "US Regional Income Convergence: A Spatial Econometric Perspective,” Regional Studies, 33, 143-156.

Roback, Jennifer. 1982. “Wages, Rents, and the Quality of Life,” Journal of Political Economy, 90, 1257-1278.

Salvino, Robert. 2007. “Home Rule Effects On State and Local Government Size,” Urban and Regional Analysis Group Working Paper No. 701, Andrew Young School of Policy Studies, Georgia State University.

Stansel, Dean. 2005. "Local decentralization and local economic growth: A crosssectional examination of US metropolitan areas," Journal of Urban Economics, 57, 5572 .

Xie, D., H. Zou, and H. Davoodi. 1999. "Fiscal Decentralization and Economic Growth in the United States,” Journal of Urban Economics, 45, 228-239.

Zax, Jeffrey S. 1989. “Is There a Leviathan in Your Neighborhood?” American Economic Review, 79, 560-567.

Zhang, Tao and H. Zou. 1998. "Fiscal Decentralization, Government Spending and Economic Growth in China,” Journal of Public Economics, 67, 221-240. 
TABLE 1: Summary Statistics for U.S. Counties

\begin{tabular}{|c|c|c|c|c|}
\hline \multirow[b]{2}{*}{ Variable } & \multirow[b]{2}{*}{ Sources } & \multicolumn{3}{|c|}{ Mean Values } \\
\hline & & All & Metro $^{\mathbf{a}}$ & Nonmetro \\
\hline Population Growth 1970-2000 (\%) & Census & 42.954 & 73.807 & 35.010 \\
\hline Employment Growth 1970-2000 (\%) & Census & 82.941 & 129.353 & 70.991 \\
\hline RPCI Growth 1969-1999 (\%) & Census Real Money Income Per Capita & 62.598 & 63.576 & 62.346 \\
\hline Population Growth 1960-1970 (\%) & Census & 5.434 & 22.105 & 1.142 \\
\hline Employment Growth 1960-1970 (\%) & Census & 10.699 & 29.792 & 5.783 \\
\hline Income Growth 1959-1969 (\%) & Census Real Money Income Per Capita & 45.797 & 39.534 & 47.409 \\
\hline Total Local Govts 1972 & Census of Govt., CGF ${ }^{\mathrm{d}}$ & 25.876 & 41.496 & 21.975 \\
\hline Per 100k Residents & Census of Govt., CGF, 1970 population & 149.220 & 43.181 & 176.522 \\
\hline Per Square Mile & Census of Govt., CGF & 0.094 & 0.133 & 0.084 \\
\hline General Purpose Govts $1972^{\mathrm{b}}$ & Census of Govt. CGF & 12.971 & 18.890 & 11.447 \\
\hline Per 100k Residents & Census of Govt., CGF, 1970 population & 75.877 & 22.203 & 89.696 \\
\hline Per Square Mile & Census of Govt., CGF & 0.052 & 0.073 & 0.047 \\
\hline Single Purpose Govts $1972^{\mathrm{c}}$ & Census of Govt., CGF & 12.905 & 22.606 & 10.407 \\
\hline Per 100k Residents & Census of Govt., CGF, 1970 population & 73.343 & 20.977 & 86.826 \\
\hline School Districts & Census of Govt., CGF, 1970 population & 32.499 & 8.029 & 38.800 \\
\hline Special Districts & Census of Govt., CGF, 1970 population & 40.844 & 12.948 & 48.026 \\
\hline Per Square Mile & Census of Govt., CGF & 0.042 & 0.060 & 0.037 \\
\hline School Districts & Census of Govt., CGF & 0.019 & 0.033 & 0.016 \\
\hline Special Districts & Census of Govt., CGF & 0.022 & 0.027 & 0.021 \\
\hline County Revenue Ratio, 1972 & Census of Govt., CGF, defined in text & 0.317 & 0.305 & 0.321 \\
\hline Population (000) 1970 & Census & 63.727 & 225.778 & 22.004 \\
\hline Employment (000) 1970 & Census & 23.986 & 87.270 & 7.718 \\
\hline $\begin{array}{l}\text { Real Per Capita Money Income } 1969 \\
\quad \text { (000), \$1969 }\end{array}$ & Census Real Money Income Per Capita & 2.409 & 2.891 & 2.285 \\
\hline Unemployment Rate 1970 & Census, City and County Databook, 1972 & 0.045 & 0.041 & 0.046 \\
\hline MSA Pop. (000) 1970, Excl. County & Author Calculations & 141.437 & 690.772 & 0.000 \\
\hline Mining Employment Share, 1970 & U.S. BEA, Author Calculations & 0.024 & 0.010 & 0.028 \\
\hline Construction Employment Share, 1970 & U.S. BEA, Author Calculations & 0.056 & 0.058 & 0.055 \\
\hline Manufacturing Employment Share, 1970 & U.S. BE, Author Calculations & 0.192 & 0.223 & 0.184 \\
\hline Trade, Trans. Util. Empl. Share, 1970 & U.S. BEA, Author Calculations & 0.049 & 0.050 & 0.049 \\
\hline Wholesale Trade Empl. Share, 1970 & U.S. BEA, Author Calculations & 0.030 & 0.035 & 0.028 \\
\hline Retail Trade Empl. Share, 1970 & U.S. BEA, Author Calculations & 0.178 & 0.163 & 0.182 \\
\hline Fin., Ins., R.E. Empl. Share, 1970 & U.S. BEA, Author Calculations & 0.055 & 0.060 & 0.053 \\
\hline Services Employment Share, 1970 & U.S. BEA, Author Calculations & 0.184 & 0.182 & 0.184 \\
\hline Government Employment Share, 1970 & U.S. BEA, Author Calculations & 0.219 & 0.209 & 0.222 \\
\hline $\begin{array}{l}\text { Percent of Pop 25+ with } \\
\text { 16+ Yrs. Schooling } 1970\end{array}$ & U.S. Census Bureau & 0.073 & 0.098 & 0.066 \\
\hline Natural Amenities Scale & USDA, Economic Research Service & 0.054 & 0.253 & 0.003 \\
\hline Distance To Own MSA, KM & Computed by authors & 5.090 & 24.859 & 0.000 \\
\hline Distance To MSA, KM & Computed by authors & 88.438 & 0.000 & 111.208 \\
\hline Incr. Dist. To MSA: Pop> 250k in 1970 & Computed by authors & 54.720 & 34.804 & 59.848 \\
\hline Inc. Dist. To MSA: Pop> 500k in 1970 & Computed by authors & 44.132 & 38.864 & 45.489 \\
\hline Incr. Dist. To MSA: Pop> 1,500k in 1970 & Computed by authors & 190.312 & 165.537 & 196.691 \\
\hline
\end{tabular}




\begin{tabular}{|c|c|c|c|c|c|c|}
\hline & \multicolumn{2}{|c|}{ Population 70-00 } & \multicolumn{2}{|c|}{ Employment 70-00 } & \multicolumn{2}{|c|}{ Real Income 70-00 } \\
\hline & Metro & Nonmetro & Metro & Nonmetro & Metro & Nonmetro \\
\hline & Coeff. & Coeff. & Coeff. & Coeff. & Coeff. & Coeff. \\
\hline \multicolumn{7}{|l|}{ Fiscal Decentralization } \\
\hline GP Govt. Per Capita & 0.00005 & $-0.0001+$ & -0.0003 & $-0.0002^{\wedge}$ & 0.0001 & 0.00002 \\
\hline GP Govt. Per Sqmi & -0.0998 & 0.0056 & -0.1009 & 0.0205 & -0.0149 & 0.0030 \\
\hline SP Govt. Per Capita & $-0.0010 *$ & -0.0001 & -0.0008 & $0.0001^{*}$ & -0.0004 & -0.00001 \\
\hline SP Govt. Per Sqmi & $0.2086^{*}$ & 0.0225 & $0.2189 *$ & -0.0021 & 0.0339 & 0.0009 \\
\hline County Revenue Ratio & 0.0278 & -0.0265 & -0.0165 & -0.0505 & $-0.0579 *$ & -0.0272 \\
\hline \multicolumn{7}{|l|}{ Control Variables } \\
\hline In Population 1970 & $-0.1394 \wedge$ & $-0.0351^{\wedge}$ & -- & -- & $-0.0248 \wedge$ & $-0.0161^{\wedge}$ \\
\hline In Employment 1970 & -- & -- & $-0.1899 \wedge$ & $-0.0322^{\wedge}$ & -- & -- \\
\hline In Per Capita Inc. 1969 & $-0.3980^{\wedge}$ & 0.0538 & $-0.3183 \wedge$ & 0.0473 & $-0.4353^{\wedge}$ & $-0.5226^{\wedge}$ \\
\hline Pop. Gr.: 1960-1970 & $1.0383^{\wedge}$ & $0.9367 \wedge$ & -- & -- & -- & -- \\
\hline Emp. Gr.: 1960-1970 & -- & -- & $0.9859 \wedge$ & $0.7100^{\wedge}$ & -- & -- \\
\hline Real Per Cap. Inc. Gr.: 1959-69 & -- & -- & -- & -- & $0.4275^{\wedge}$ & $-0.0840^{\wedge}$ \\
\hline ln MSA Pop. 1970, Ex. County & 0.0042 & -- & 0.0069 & -- & $0.0102^{\wedge}$ & -- \\
\hline Unemp. Rate 1970 & $-4.1864 \wedge$ & $0.7261 \wedge$ & -1.2396 & $1.5014^{\wedge}$ & $-2.2398 \wedge$ & $-0.8186 \wedge$ \\
\hline Mining Shr. 1970 & $-2.9840^{\wedge}$ & $-0.5171+$ & $-2.1630^{\wedge}$ & -0.5874 & $-0.3328+$ & -0.0026 \\
\hline Construction Shr. 1970 & $-1.4981 \wedge$ & 0.0736 & $-0.4416^{*}$ & 0.3434 & 0.2683 & $0.3817 \wedge$ \\
\hline Manufacturing Shr. 1970 & $-2.4960^{\wedge}$ & -0.1828 & $-1.8140^{\wedge}$ & -0.2826 & $-0.3408 \wedge$ & 0.0330 \\
\hline Trade, Trans., Util. Shr. 1970 & $-2.7194 \wedge$ & -0.2791 & $-2.1305^{\wedge}$ & -0.3245 & $-0.4228 \wedge$ & -0.0614 \\
\hline Wholesale Trade Shr. 1970 & $-2.4076^{\wedge}$ & $-0.7201 \wedge$ & $-1.4500+$ & $-0.5542+$ & -0.3034 & -0.0040 \\
\hline Retail Trade Shr. 1970 & $-2.6933^{\wedge}$ & 0.2195 & $-1.9909 \wedge$ & 0.1158 & $-0.5021^{\wedge}$ & -0.0956 \\
\hline Fin., Ins., R.E. Shr. 1970 & -0.5919 & $0.6450^{\wedge}$ & 0.4140 & $1.0107 \wedge$ & 0.2180 & $0.6729 \wedge$ \\
\hline Services Shr. 1970 & $-2.5948 \wedge$ & 0.2693 & $-2.1241^{\wedge}$ & 0.0958 & -0.0418 & $0.1643^{\wedge}$ \\
\hline Govt. Shr. 1970 & $-2.8530^{\wedge}$ & -0.1176 & $-1.8401^{\wedge}$ & 0.1904 & $-0.3151^{\wedge}$ & -0.0055 \\
\hline Ed. Att. 1970 & 0.3643 & $-0.4835+$ & $0.8605+$ & -0.0815 & $0.9071^{\wedge}$ & $0.4099 \wedge$ \\
\hline Amenities Scale & 0.0022 & $0.0370^{\wedge}$ & 0.0127 & $0.0406^{\wedge}$ & $0.0202^{\wedge}$ & $0.0148 \wedge$ \\
\hline Min. Dist. Own MSA & 0.0010 & -- & 0.0002 & -- & -0.0004 & -- \\
\hline Min. Dist To MSA & -- & $-0.0011^{\wedge}$ & -- & $-0.0013^{\wedge}$ & -- & $-0.0005^{\wedge}$ \\
\hline Incr. Dist. MSA > 250k Pop. & $-0.0005+$ & $-0.0007 \wedge$ & $-0.0008 \wedge$ & $-0.0009 \wedge$ & $-0.0004 \wedge$ & $-0.0004^{\wedge}$ \\
\hline Incr. Dist. MSA > 500k Pop. & -0.0001 & $-0.0002 *$ & -0.0003 & $-0.0003+$ & $-0.0003^{\wedge}$ & $-0.0002^{\wedge}$ \\
\hline Incr. Dist. MSA > 1500k Pop. & 0.0001 & 0.00001 & 0.0002 & -0.00002 & $-0.0001+$ & $-0.0001^{\wedge}$ \\
\hline Constant & $4.8475^{\wedge}$ & $0.6634+$ & $4.4086^{\wedge}$ & $0.6990 *$ & $1.3365^{\wedge}$ & $1.1291^{\wedge}$ \\
\hline$\lambda$ & \multicolumn{2}{|c|}{$0.4900^{\wedge}$} & \multicolumn{2}{|c|}{$0.4890^{\wedge}$} & \multicolumn{2}{|c|}{$0.3480^{\wedge}$} \\
\hline State Fixed Effects & \multicolumn{2}{|c|}{ Yes } & \multicolumn{2}{|c|}{ Yes } & \multicolumn{2}{|c|}{ Yes } \\
\hline Obs. & \multicolumn{2}{|c|}{3072} & \multicolumn{2}{|c|}{3072} & \multicolumn{2}{|c|}{3072} \\
\hline Adj. R-Squared & \multicolumn{2}{|c|}{0.6929} & \multicolumn{2}{|c|}{0.6471} & \multicolumn{2}{|c|}{0.5955} \\
\hline Akaike Information Criterion & \multicolumn{2}{|c|}{-2.9774} & \multicolumn{2}{|c|}{-2.7220} & \multicolumn{2}{|c|}{-4.4729} \\
\hline Schwartz Criterion & \multicolumn{2}{|c|}{-2.6967} & \multicolumn{2}{|c|}{-2.4413} & \multicolumn{2}{|c|}{-4.1922} \\
\hline Log-Likelihood & \multicolumn{2}{|c|}{1347.09} & \multicolumn{2}{|c|}{956.55} & 368 & \\
\hline
\end{tabular}




\begin{tabular}{|c|c|c|c|c|c|c|}
\hline & \multicolumn{2}{|c|}{ Population 70-00 } & \multicolumn{2}{|c|}{ Employment 70-00 } & \multicolumn{2}{|c|}{ Real Income 69-99 } \\
\hline & Metro & Nonmetro & Metro & Nonmetro & Metro & Nonmetro \\
\hline & Coeff. & Coeff. & Coeff. & Coeff. & Coeff. & Coeff. \\
\hline \multicolumn{7}{|l|}{ Fiscal Decentralization } \\
\hline GP Govt. Per Capita & 0.00001 & $-0.0001+$ & -0.00037 & $-0.0002^{\wedge}$ & 0.00018 & 0.00002 \\
\hline GP Govt. Per Sqmi & -0.0602 & 0.0131 & -0.0584 & 0.0281 & -0.0187 & 0.0066 \\
\hline Sp. Dist. Per Capita & -0.0009 & 0.0000 & -0.0008 & 0.0001 & -0.0004 & -0.00002 \\
\hline Sch. Dist. Per Capita & -0.0016 & -0.0001 & -0.0007 & 0.0001 & -0.0007 & -0.00001 \\
\hline Sp. Dist. Per Square Mile & $0.5722^{\wedge}$ & 0.0448 & $0.6083^{\wedge}$ & 0.0230 & -0.0094 & 0.0106 \\
\hline Sch. Dist. Per Square Mile & 0.1127 & -0.0173 & 0.1149 & -0.0438 & 0.0431 & -0.0143 \\
\hline County Revenue Ratio & 0.0380 & -0.0262 & -0.0073 & -0.0520 & $-0.0584^{*}$ & -0.0274 \\
\hline \multicolumn{7}{|l|}{ Control Variables } \\
\hline ln Population 1970 & $-0.1460^{\wedge}$ & $-0.0345^{\wedge}$ & -- & -- & $-0.0244 \wedge$ & $-0.0163 \wedge$ \\
\hline ln Employment 1970 & -- & -- & $-0.1959 \wedge$ & $-0.0329 \wedge$ & -- & -- \\
\hline ln Per Capita Inc. 1969 & $-0.3971^{\wedge}$ & 0.0523 & $-0.3198^{\wedge}$ & 0.0490 & $-0.4337 \wedge$ & $-0.5217 \wedge$ \\
\hline Pop. Gr.: 1960-70 & $1.0389 \wedge$ & $0.9389 \wedge$ & -- & -- & -- & -- \\
\hline Emp. Gr.: 1960-70 & -- & -- & $0.9851^{\wedge}$ & $0.7085^{\wedge}$ & -- & -- \\
\hline Real Per Cap. Inc. Gr.: 1959-69 & -- & -- & -- & -- & $0.4287 \wedge$ & $-0.0835^{\wedge}$ \\
\hline ln MSA Pop., 1970, Ex. County & 0.0056 & & 0.0083 & & $0.0101^{\wedge}$ & \\
\hline Unemp. Rate 1970 & $-4.1441^{\wedge}$ & $0.7241^{\wedge}$ & -1.2662 & $1.5046^{\wedge}$ & $-2.2239 \wedge$ & $-0.8166^{\wedge}$ \\
\hline Mining Shr. 1970 & $-2.8446^{\wedge}$ & $-0.5116^{*}$ & $-2.0242^{\wedge}$ & $-0.5922 *$ & $-0.3417+$ & -0.0020 \\
\hline Construction Shr. 1970 & $-1.3413^{\wedge}$ & 0.0803 & -0.2660 & 0.3348 & 0.2472 & $0.3814 \wedge$ \\
\hline Manufacturing Shr. 1970 & $-2.3535^{\wedge}$ & -0.1795 & $-1.6558^{\wedge}$ & -0.2900 & $-0.3595 \wedge$ & 0.0328 \\
\hline Trade, Trans., Util. Shr. 1970 & $-2.5697 \wedge$ & -0.2786 & $-1.9617 \wedge$ & -0.3292 & $-0.4425^{\wedge}$ & -0.0613 \\
\hline Wholesale Trade Shr. 1970 & $-2.2024 \wedge$ & $-0.7147 \wedge$ & $-1.2128^{*}$ & $-0.5610+$ & -0.3324 & -0.0064 \\
\hline Retail Trade Shr. 1970 & $-2.5328 \wedge$ & 0.2253 & $-1.8380^{\wedge}$ & 0.1142 & $-0.5104 \wedge$ & -0.0955 \\
\hline Fin., Ins., R.E. Shr. 1970 & -0.4431 & $0.6580^{\wedge}$ & 0.5632 & $0.9958^{\wedge}$ & 0.2048 & $0.6715^{\wedge}$ \\
\hline Services Shr. 1970 & $-2.4738^{\wedge}$ & 0.2736 & $-1.9809 \wedge$ & 0.0914 & -0.0610 & $0.1650^{\wedge}$ \\
\hline Govt. Shr. 1970 & $-2.7183^{\wedge}$ & -0.1091 & $-1.6925^{\wedge}$ & 0.1841 & $-0.3322^{\wedge}$ & -0.0059 \\
\hline Ed. Att. 1970 & 0.3901 & $-0.4830+$ & $0.8902+$ & -0.0786 & $0.9038 \wedge$ & $0.4106^{\wedge}$ \\
\hline Amenities Scale & 0.0025 & $0.0369 \wedge$ & 0.0130 & $0.0404 \wedge$ & $0.0202^{\wedge}$ & $0.0148^{\wedge}$ \\
\hline Min. Dist. Own MSA & 0.0009 & -- & 0.0001 & -- & -0.0004 & -- \\
\hline Min. Dist To MSA & -- & $-0.0011^{\wedge}$ & -- & $-0.0013^{\wedge}$ & -- & $-0.0005^{\wedge}$ \\
\hline Incr. Dist. MSA > 250k Pop. & $-0.0005^{\wedge}$ & $-0.0007 \wedge$ & $-0.0008^{\wedge}$ & $-0.0009 \wedge$ & $-0.0004 \wedge$ & $-0.0004 \wedge$ \\
\hline Incr. Dist. MSA >500k Pop. & -0.00003 & $-0.0002 *$ & -0.0002 & $-0.0003+$ & $-0.0004 \wedge$ & $-0.0002^{\wedge}$ \\
\hline Incr. Dist. MSA >1500k Pop. & 0.0001 & 0.00001 & 0.0002 & -0.00002 & $-0.0001+$ & $-0.0001^{\wedge}$ \\
\hline Constant & $4.7653^{\wedge}$ & $0.6524+$ & $4.3058^{\wedge}$ & $0.7117^{*}$ & $1.3481^{\wedge}$ & $1.1304 \wedge$ \\
\hline$\lambda$ & \multicolumn{2}{|c|}{$0.4930^{\wedge}$} & \multicolumn{2}{|c|}{$0.4950^{\wedge}$} & \multicolumn{2}{|c|}{$0.3430^{\wedge}$} \\
\hline State Fixed Effects & \multicolumn{2}{|c|}{ Yes } & \multicolumn{2}{|c|}{ Yes } & \multicolumn{2}{|c|}{ Yes } \\
\hline Obs. & \multicolumn{2}{|c|}{3072} & \multicolumn{2}{|c|}{3072} & \multicolumn{2}{|c|}{3072} \\
\hline Adj. R-Squared & \multicolumn{2}{|c|}{0.6934} & \multicolumn{2}{|c|}{0.6477} & \multicolumn{2}{|c|}{0.5948} \\
\hline Akaike Information Criterion & \multicolumn{2}{|c|}{-2.9769} & \multicolumn{2}{|c|}{-2.7227} & \multicolumn{2}{|c|}{-4.4702} \\
\hline Schwartz Criterion & \multicolumn{2}{|c|}{-2.6884} & \multicolumn{2}{|c|}{-2.4342} & \multicolumn{2}{|c|}{-4.1817} \\
\hline Log-Likelihood & 13 & & 95 & & & \\
\hline
\end{tabular}

$*, * *, * * *$ indicate significance (two-tailed) at the $10 \%, 5 \%$, and $1 \%$ levels, respectively 


\section{Endnotes}

${ }^{1}$ A report by the NCSL (1997: 3-5) shows this in terms of the percent of state and local tax revenue raised by state governments. Brunori (2003) provides a detailed review of the role property taxation in local fiscal autonomy.

${ }^{2}$ For instance, Davoodi and Zou (1998), Zhang and Zou (1998), Xie, Zou, and Davoodi (1999) found a negative relationship between fiscal decentralization and growth using data sets based on panels of developed countries, Chinese provinces, and U.S. states, during the 1970s, 1980s, and early 1990s. Other studies conflict with these findings by showing evidence of a positive relationship between fiscal decentralization and economic growth. For example, Lin and Liu (2000) using Chinese provinces and Akai and Sakata (2002) using U.S. states.

${ }^{3}$ These studies utilize measures of government structure that include population-based measures of central-city dominance and municipal fragmentation, as well as measure of special-purpose government fragmentation per capita and special-purpose governments relative to total governments in the metropolitan area.

${ }^{4}$ Roback (1982) developed a model of compensating differentials in labor markets and showed evidence that local amenities can explain regional wage differences.

${ }^{5}$ Similarly, Panizza (1999), and Arzhagi and Henderson (2005) examined determinants of fiscal federalism by developing models of welfare maximizing decentralization (or centralization in the case of Panizza, 1999).

${ }^{6}$ These papers show that fiscal decentralization increases with population size and heterogeneity, which are factors that enhance taste differentiation.

${ }^{7}$ There may be some concern about collinearity between the per capita measures and the per square mile measures, however, the correlation coefficients tend to be small, varying from +0.03 for general-purpose governments to +0.04 for single-purpose governments. 
${ }^{8}$ Metropolitan statistical areas are designated by the federal Office of Management and Budget to reflect sub-state local labor market areas. They do not generally conform to political jurisdictions.

${ }^{9}$ For our state fixed effects, Alabama is the excluded state for both metropolitan and nonmetropolitan regions. We also drop nonmetropolitan binary variables for Rhode Island and the District of Columbia because they contained no nonmetropolitan counties in 1973. Similarly, we drop metropolitan binary variables for Vermont and Wyoming since they contained no metropolitan counties.

${ }^{10}$ For our industry employment shares, we exclude Agricultural Services from the regression to avoid perfect collinearity.

${ }^{11}$ We also run our model for counties that were nonmetropolitan in 1973 but changed status to metropolitan by 2003. The results are qualitatively similar to those for all nonmetropolitan counties. Thus, we do not find much evidence that nonmetropolitan counties were designing decentralization policy in anticipation of metropolitan status.

${ }^{12}$ We treat independent cities as county equivalents.

${ }^{13}$ Our indicator of income comes from the Census Bureau, which measures money income. This measure reflects income flows by place of residence from a variety of sources, including earnings from work, asset income, and transfers. However, it differs significantly from personal income, measure by the U.S. Bureau of Economic Analysis, in that it excludes payments in kind (such as food stamps, Medicare, and Medicaid payments).

14 The coefficient on initial population (income), which is commonly referred to as the conditional convergence coefficient, must be interpreted carefully as Quah (1993) has forcefully argued. In particular, Quah (1993) shows that a significant negative coefficient on initial income in a cross-section growth regression does not imply that income levels 
are becoming more similar during the estimation period. We do not place the convergence interpretation on the coefficient of initial population (income). Rather we view it as indicating that initially lower income areas have tended to grow faster than initially higher income areas, after accounting for steady-state determinants, which is what we observe.

15 These results are available from the authors upon request. 